Original scientific paper - Izvorni znanstveni rad

UDK: 65.011 .4

\title{
Potential impact of EU Common Agriculture Policy on Croatian dairy sector - modelling results
}

\author{
doi: $10.15567 /$ mljekarstvo.2015.0306 \\ Magdalena Zrakić ${ }^{*}$, Guna Salputra ${ }^{2}$, Vladimir Levak ${ }^{1}$ \\ ${ }^{1}$ University of Zagreb, Faculty of Agriculture, Svetošimunska cesta 25, 10000 Zagreb, Croatia \\ ${ }^{2}$ University of Ljubljana, Biotechnical Faculty, Groblje 3, Domžale, Slovenia \\ Received - Prispjelo: 17.11.2014. \\ Accepted - Prihvaćeno: 01.06.2015.
}

\begin{abstract}
Milk in terms of production value has the second biggest share in Croatian agricultural sector in 2013 (CBS, 2014). It could be speculated that after the abolition of quotas in the European Union, the declining trend in domestic production will continue and that exposure to free European market will significantly affect the competitiveness of domestic production. The aim of this paper is to analyse the prospects of Croatian dairy industry (sector) under certain conditions of the EU Common Agricultural Policy (CAP) and to present projections simulated with the help of partial equilibrium model AGMEMOD. The main model inputs are policy and macroeconomic variables, supply-use balances of agro-food products and producer prices. The Baseline projections has shown that in 2025 in line with the CAP implementation there might be a decrease of dairy cows number by $33 \%$, the raw milk price by $14 \%$ and the collected cow's milk amount by $13 \%$ compared to the five-year average of 2008-2012. The positive effect was noted in productivity, according to the simulation, with an increase by $25 \%$, which consequently may lead to increased deliveries to dairies for about $17 \%$. Therefore preliminary results show that accounting for milk processing the dairy sector in Croatia might obtain a favourable situation by 2025. Taking into account the EU market situation, there is an opportunity to increase milk processing given the current level of prices in the EU market and global markets, and taking into account the abolition of milk quotas. Also, the results suggest, according to the experience of other states, that the utilization of funds of $1^{\text {st }}$ and $2^{\text {nd }}$ pillar of the CAP (utilization measures across projects) in order to improve the production structure and efficiency will play an important role.
\end{abstract}

Key words: milk and dairy products, the Common Agricultural Policy, partial equilibrium model projections

\section{Introduction}

By joining the EU, Croatia became a part of the community of 14 million agricultural producers which together with employees in the food sector constitute about $7 \%$ of total EU employment and generate $6 \%$ of EU gross domestic product. Comparing to the EU, Croatian agriculture has modest results, in both terms: structural and production indicators and also in terms of economic indicators. Significance of Croatian agriculture, related to the EU framework for most major general indicators(production value, $0.7 \%$; Gross value added, $0.8 \%$; farms $1.9 \%$; labour force $1.9 \%$; utilized agricultural area $0.8 \%$; livestock (LU) $0.8 \%$; export to EU, $0.8 \%$; imports from EU, $0.2 \%$ ) does not exceed $2 \%$ (Jurišić, 2013).

The total production value of the European Union (EU) livestock sector is about 169 billion euros. 
Milk (35\%), beef and pig meat (each around $20 \%$ ) are the sectors with the highest production value (Eurostat, 2013). The task of EU dairy policy which started during 1960s was/is to create stable market conditions for all producers and processors in EU, and to motivate producers to produce more. Later policy through its measures were made efforts to encourage producers to be more market oriented (Muminović, 2012), not to be policy money dependent.

In European Union (EU), 143 billion litres ${ }^{1}$ of raw milk (all types) per year are transformed into large variety of products (Eurostat, 2014). Milk is one of the most important sources of nutrition and strategically important product throughout the world. Various dairy products such as drinking milk, cheese, fresh dairy products and butter play a very important role in the diet of all consumers in Europe. The most valuable product of the dairy sector is raw milk (DairyCO Market Information, 2014), as it takes up approximately $14 \%$ of agricultural output in EU. Amount of total milk collected in Croatia was only $0.36 \%$ of the EU milk production in 2013 where France, Netherlands, Germany, United Kingdom, Italy and Poland are market leaders and produce more that $70 \%$ of total milk. Croatia is self-sufficient with drinking milk, butter, cream and fresh dairy products while is importing around $20 \%$ of cheese consumed and major part of milk powders. (Eurostat, 2014; Croatian Bureau of Statistics, 2014)

Croatia joined to the EU on $1^{\text {st }}$ of July 2013 becoming the member of the common market and Common Agricultural Policy (CAP) of the EU as well. During the negotiation process the agricultural sector and food processing chain have been core topics. Since the signing of the Stabilisation and Association Agreement (SAA) which entered into force in 2005, Croatia's trade with the EU has been systematically liberalised. One of the sectors the most affected by these changes is Croatian dairy sector (Šakić Bobić et al., 2009). Croatia has switch from mostly coupled direct payments to regional and historical payments as they are in line with the EU CAP. The quota system in the EU for milk sold to processors and directly on markets will be abolished in 2015 . Therefore despite Croatia obtained its own quota
765 thousand tons, the sector will have to operate under free market and competition conditions within the EU soon. The subsidies coupled to milk production in Croatia in 2013 were 18 million euros what is a huge drop from their top level - 109 million euros in 2010. During this period a milk production dropped by almost $20 \%$. At the same time amount of raw milk purchased by processors remained stable because of import of raw milk which increased ten times in 2013 compared to 2010.

Modeling approach is a method that is often used in agricultural economics at both the micro (Prišenk et al., 2014) and macro (Kotevska et al., 2013) level analysis of the agricultural sector. The model enables view of real situations, under certain conditions. With this method, with an emphasis on mathematical models, it is enabled the system overview and analysis of the relationship between the main factors analyzed the situation (Zrakić et al., 2014).

For the quantitative analysis of policy (quota abolition, direct payments) and trade conditions (trade regimes) impacts on milk and dairy market there can be various approaches. The most common approaches are CGE (general equilibrium), $\mathrm{PE}$ (partial equilibrium), programming models and cost function econometric estimation. Chantreuil at al. (2008) made projection analysis of milk and dairy market under a baseline of no policy change for a time horizon of 10 years for selected individual member states (MS), the EU15 and EU12 in aggregate using PE model. The study showed that external variables like supply and demand for dairy products on world market (as reflected in the baseline) have more important effect and influence at the future level of EU dairy product prices, milk prices and dairy production than the changes in the milk quota regime which are analysed. Macro level analysis of accession effects for Croatia has been done by applying CGE model (Boulanger et al., 2013), but there were no detailed analysis about effects on agricultural sector made by PE model yet. The purpose of this study is to analyse perspectives for Croatian milk and dairy sector under certain policy conditions within the EU and to present projections simulated with the help of PE AGMEMOD model. Grbić et al., 2010, reported that quota system was inefficient

${ }^{1}$ Eurostat for EU-28 (2012) 
in terms of reduction of production costs, if they are in some way determined by manner (quantity) of production. One could raise a hypothesis that after the abolition of quotas in the EU, the trend of declining production will continue and further weaken the domestic dairy sector. Modelling a market effects at EU level might help to approve or to refuse the above statement. Therefore the hypothesis of this paper is that the Croatian accession to the EU can have a positive impact on the dairy industry of Croatia including those farmers who have adapted their production to the EU conditions.

\section{Materials and methods}

\section{Model development process}

The model used to analyse the impacts of Croatia's accession to the EU, according to application of policy measures in agriculture, is AGriculture MEmber State MODelling (AGMEMOD) partnership tool. AGMEMOD model is an econometric, dynamic, partial equilibrium, multi-country, multi-market model. Based on a set of commodity specific model templates, country specific models were developed in order to reflect the details of EU agriculture at member states level and at the same time allowing their combination in an EU model (Chantreuil et al., 2012). In the current model program version the indicators of agricultural production are estimated until 2025. Although the new programming period in the EU runs from 2020, it is important to bear in mind what are the potential effects of a current policy continuation and on these findings create a new policy.

Croatian model parameters of behavioural equations are mostly econometrically estimated, however, they have been calibrated, where estimation was either not feasible or meaningful. The modelling system is solved in prices, the supply and use balances of each product at both the EU and the Member State levels holds and take into account the international trade. The dairy sub model is the most complicated due to the fact that the allocation of raw milk to dairy products is done on the basis of fat and protein content. In the first step, raw milk production, raw milk imports and exports are determined. In the second step, raw milk for feed use, farm local use and milk available for further processing is simulated. Equations of fat or protein use determine the quantity of the respective dairy products manufactured.

The dairy cow ending stock equation has the following specification:

$$
d c c t_{t}=f\left(d c c c t_{t-1}, \frac{p_{t}+p r c_{t-1}}{i c t_{t}}\right)
$$

where $d c c c t_{t}$ is the dairy cows ending stock in the year $t, p_{t}$ is the price of milk, $\operatorname{prc}_{t-1}$ is price policy reaction component which takes into account all the types of direct payments whether they are coupled, historical or regional; and ict $t_{t}$ is the milk production cost (or index) in year $t$.

Price reaction component for milk is modelled:

Prct $=(c m c p m * c m c p t t+c m h p m * b d h p t t) /(c m y p c * d c c c t)$

$+($ cmrpm * bdgrtt $) /($ ccslwt $-1 *$ ccctt $-1+$ cmypct $-1 * d c c c t t-1$

$+($ cmrpm * obnsut $) /($ uaaha * lautr * cmypc

where cmcpm, cmhpm, cmrpm - multipliers for weighting coupled (1.0), historical (0.5) and regional (0.3) payments impact; cmcpt, bdhpt, bdgrt - coupled, historical, grassland and national payments; uaaha - area harvested; lautr - livestock density; ccslw - slaughter weight. Approach in details can be found at Salputra et al., 2011.

Milk yield per cow $y p c_{t}$ is:

$$
y p c_{t}=f\left(p_{t}, i c t_{t}, \text { trend }\right)
$$


Total milk production is calculated as the product of milk yield per cow and total ending cow numbers. Fat and protein contents of standard products can be applied (e.g., $82 \%$ milk fat content in butter). The fat allocation to a dairy commodity can be written as

$$
f p c_{i, t}=f\left(f p c_{i, t-1}, p_{i, t}, V\right)
$$

Where is the allocation of fat to a dairy commodity $i$ in year $t, p_{i, t}$ is the price of dairy commodity $i$, and $V$ is a vector of exogenous variables that affect the fat allocation to commodity. Only fat allocations are estimated, as allocation to the product is determined as a balancing residual. The allocation of milk protein is determined by similar identities.

To complete the creation of the Croatian AGMEMOD dairy sub-model, it is necessary to add an equation describing the equilibrium for each prod- uct market. This condition implies that production plus beginning stocks plus imports must equal domestic use plus ending stocks plus exports.

\section{Input data}

The model input data is based on the production-consumption balance-sheets of agricultural products (dairy cows, milk and milk products) in Croatia from 2000 to 2012 (Ministry of agriculture), producer prices (Croatian Bureau of Statistics, MIS), average protein and fat content per year for dairy products and exogenous macroeconomic and policy indicators. Current policy measures in the national dairy sector ${ }^{2}$ were formed as part of a single payment (payment per hectare of arable land) and support from $0.50 \mathrm{kn} / \mathrm{kg}$ of milk. Also, Croatia has the right to pay domestic support which is not a part of the CAP for dairy cows (836 kn/head) during three years of accession. In addition, the Ministry, in order to partially mitigate the increased costs

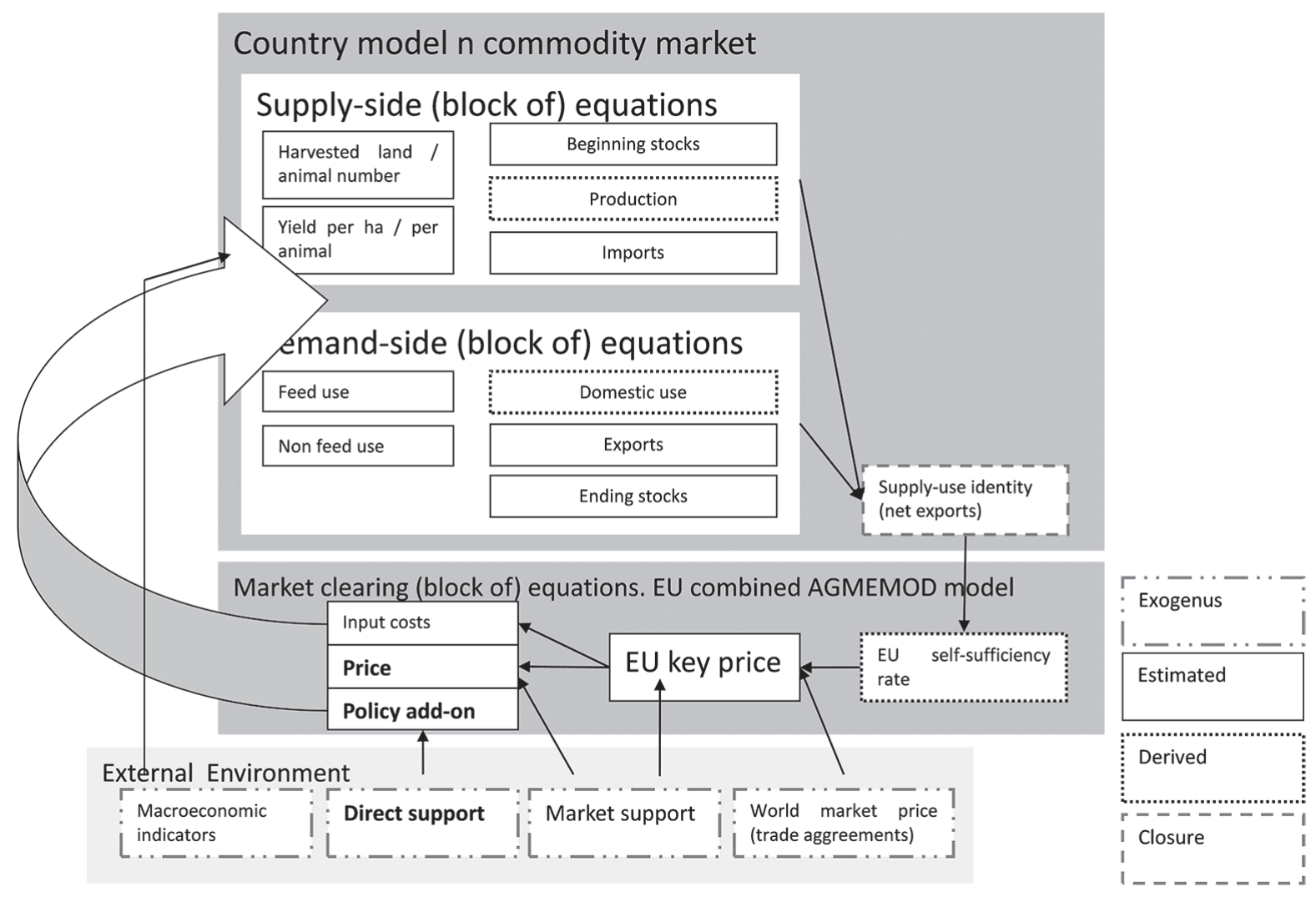

Source: Authors

Figure 1. Scheme of general AGMEMOD model structure

${ }^{2}$ The model projects the development of phenomena under certain assumptions (ceteris paribus). In the case of AGMEMOD models all other things are kept constant while the agricultural policy is input variable which changes (scenarios). 
of animal feed within the permissible aid measure called special production coupled payments that are paid additionally for support of the dairy cow (800 $\mathrm{kn}$ ) and suckler cows (500 kn). Production results according the CAP frame should be the result of market impulses (demand), and support have mainly effect the protection of farmers' income (Franić et al., 2011).

\section{Results and discussion}

Drought in the year 2012 had a negative effect on crop yields and livestock feed prices. In addition, the effects of the economic crisis on other sectors of the Croatian economy adversely affect the agricultural production. Production volume of most agricultural products (crop and livestock production) decreased. Insufficient quantity and fodder price increase with increasing energy prices have also impacted the number of animals in the livestock fund. Since 2009, the number of milk suppliers declined by more than $35 \%$. The declining number of dairy cows ranged from 23,122 (2011) to 22,700 (2013). Despite these indicators, the quantity of milk delivered by the supplier increased in the period at a $\mathrm{CAGR}^{3}$ for $12 \%$. Also, there were changes in the structure of milk producers. More than half of the milk supplied in the 2011 was delivered by the manufacturers with an annual production of more than 100,000 kg. In Croatia, the average quantity of milk supplied by the supplier was $9,000 \mathrm{~kg}$ in the 2003, while in 2012 that quantity was approximately $50,000 \mathrm{~kg}$.

Croatia is close to self-sufficient with butter, cream and fresh dairy products while is importing around $20 \%$ of cheese consumed and major part of milk powders (Eurostat, 2014; Croatian Bureau of Statistics, 2014).

Baseline projections for Croatian dairy sector suggest that until 2025 compared to average three years level (2010-2012) raw milk price will drop by $14 \%$ in Croatia.

Number of dairy cows might decrease by $33 \%$ and cows' milk collected by $13 \%$. Positive effect can be expected from increasing milk yields which can go up by $25 \%$. Average milk production per cow in EU in 2012 was $6603 \mathrm{~kg}$ and in Croatia it was $4343 \mathrm{~kg}$ (Mljekarski list 07/2013, according to IDF, Comext, CBS), so there is a possibility of increasing yields by improving technology. Continued growth of milk production successfully compensates the reduction of milk herd and during 2012 the EU grew by $1.2 \%$

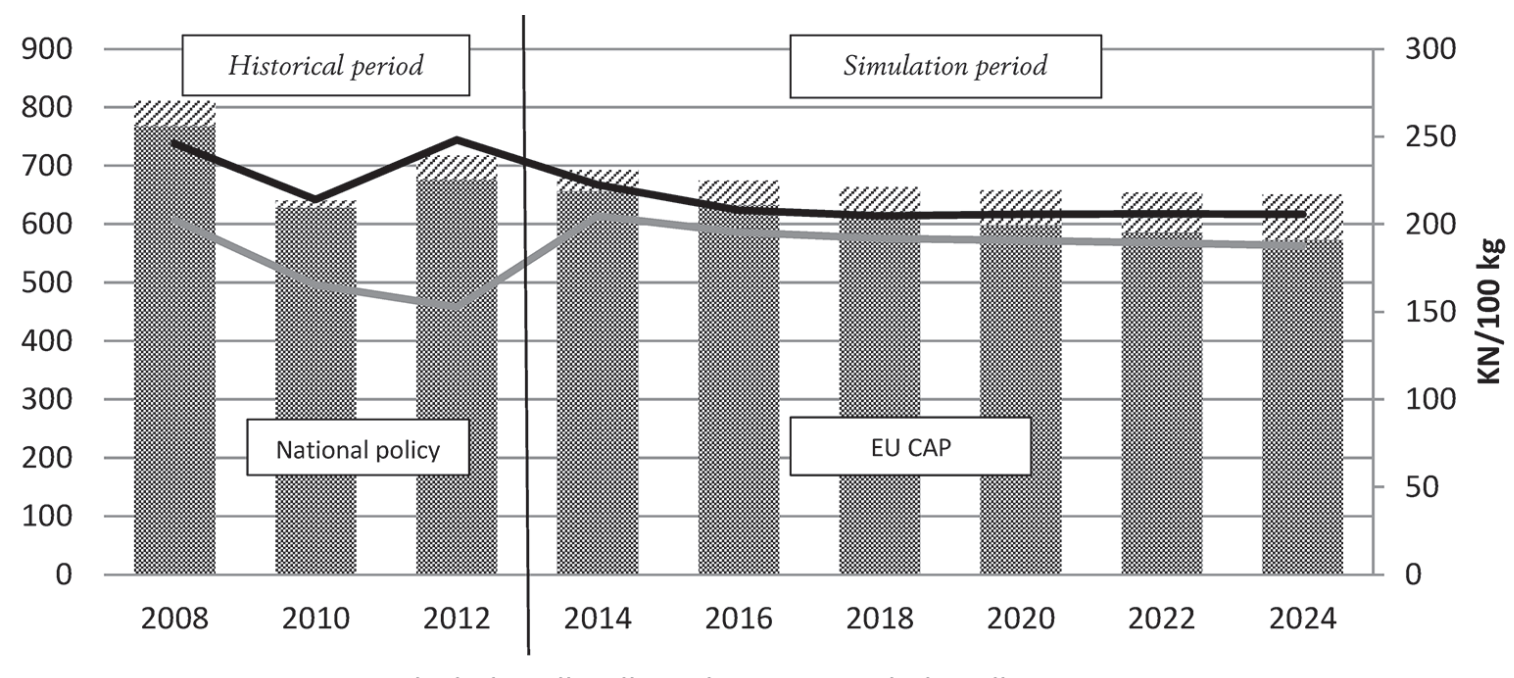

Wotal whole milk collected $\quad$

whole milk delivered to dairies $\longrightarrow$ Cow's milk - 3,7\% fat price

\section{Source: AGMEMOD-V 7.34}

Figure 2. Projections of whole milk market variables and cow's milk (3.7 \% fat) price

${ }^{3}$ The year-over-year growth rate of an investment is over a specified period of time. The compound annual growth rate is calculated by taking the $\mathrm{n}^{\text {th }}$ root of the total percentage growth rate, where $\mathrm{n}$ is the number of years in the period being considered 
(Šakić Bobić, 2013). Raw milk import is about to be increased three times, that together with decreasing feed and on farm consumption can insure that milk delivery to processors could increase by 17 $\%$ (including milk quantities that processors will import). Production of butter is expected to increase, cheese production might stay close to current level, however the drop of $5 \%$ is expected. Increasing consumption per capita will lead to decreasing selfsufficiency rates for all dairy products with exception of butter. All types of direct support measures recalculated to milk show a decrease in support by two thirds.

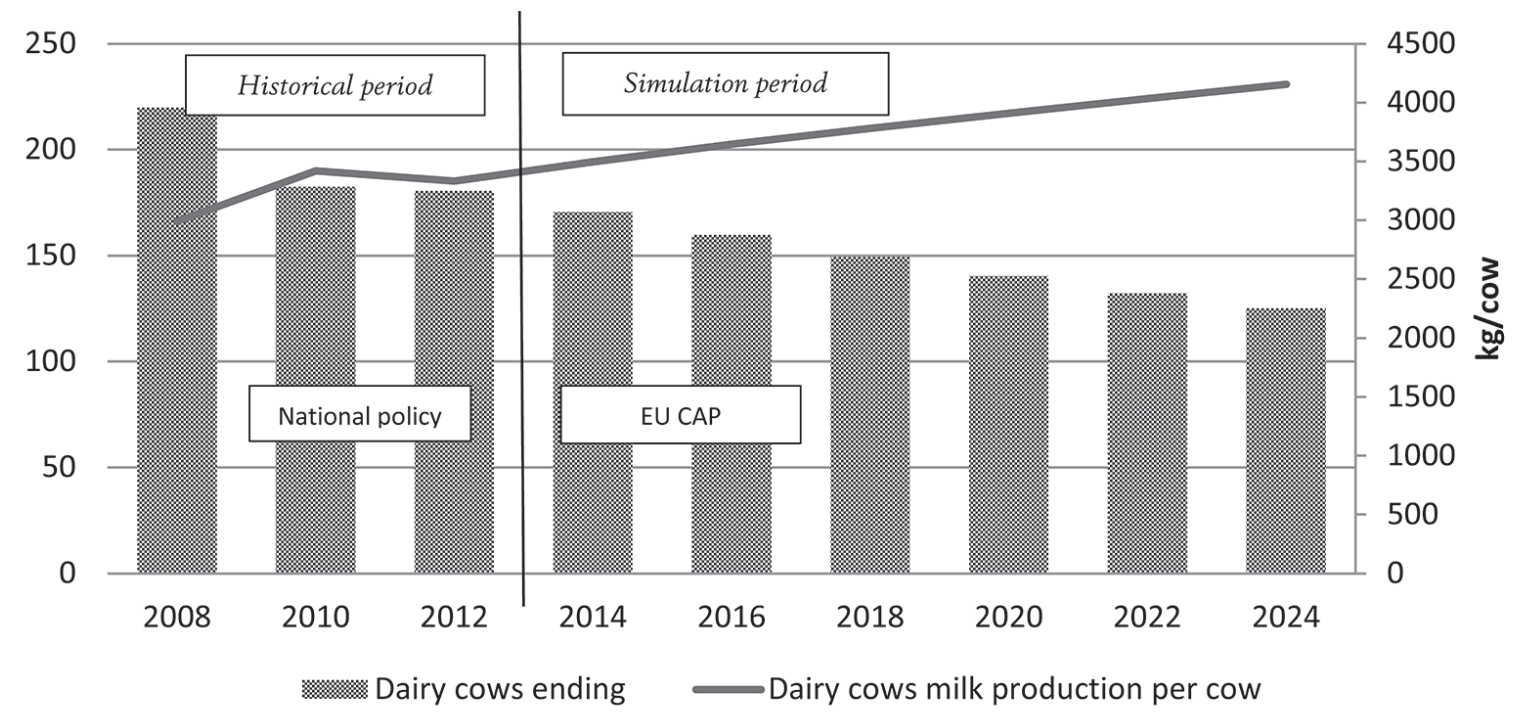

Source: AGMEMOD-V 7.34

Figure 3. Projections of dairy cow number and productivity per cow

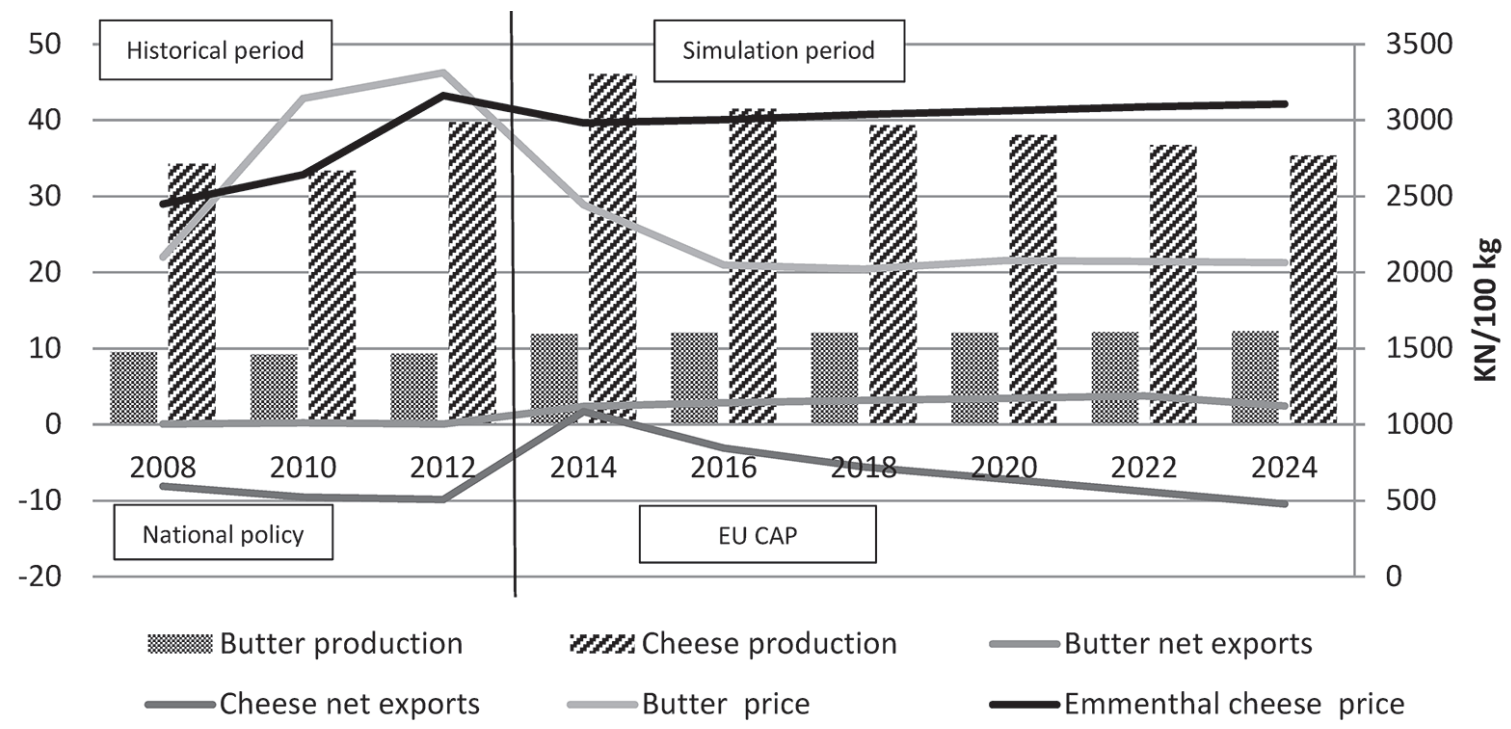

Source: AGMEMOD-V 7.34

Figure 4. Projections of butter and cheese production and net exports 


\section{Conclusions}

Preliminary results of baseline projections show the favourable situation (according to the EU dairy market trends) for Croatian dairy sector in 2025 if account for both agricultural and milk processing sector. It have an opportunity to increase production at current price level on EU and world market, taking into account the abolition of milk quotas and EU $\mathrm{CAP}$ as it is implemented in Member States since 2014. However, Croatian milk producers could be quite vulnerable with respect to changes on market, prices, production structures and CAP 2015-2020 implementation in other countries. Nevertheless, results indicate that composition of $1^{\text {st }}$ and $2^{\text {nd }}$ Pillar elements around the EU in case of fully decoupled or utmost coupled to dairy sector payments can play the background role in different scenarios, while uptake of opportunities given by CAP in terms of improvement of production structures and efficiency will play the most important role. For a large number of market factors manufacturers themselves cannot directly affect, but their actions should be adaptable on market situations.

\section{Potencijalni utjecaj Zajedničke poljoprivredne politike na hrvatski mljekarski sektor - rezultati modela}

\section{Sažetak}

Mlijeko je proizvod koji u kontekstu vrijednosti poljoprivredne proizvodnje udjelom zauzima drugo mjesto (DZS, 2013). Očekuje se da će se nakon ukidanja kvota u Europskoj uniji, trend smanjenja domaće proizvodnje nastaviti i da će izloženost slobodnom europskom tržištu znatno utjecati na konkurentnost domaće proizvodnje. Cilj rada je analizirati perspektivu hrvatske mliječne industrije (sektora) pod određenim uvjetima politike unutar Europske unije te predstaviti projekcije simulirane uz pomoć ekonometrijskog AGMEMOD modela parcijalne ravnoteže. Ulazni podaci modela su političke i makroekonomske varijable, proizvodno potrošne bilance proizvoda, proizvođačke cijene te udio masti i bjelančevina u mliječnim proizvodima. Polazni scenarij (primjena Zajedničke poljoprivredne politike od 2013.) pokazao je da će se do 2025. godine smanjiti broj mliječnih krava (za 33 \%), cijena sirovog mlijeka (za $14 \%$ ) i količina prikupljenog kravljeg mlijeka (za $13 \%$ ) u odnosu na četverogodišnji prosjek 2008/2012. Prema simulaciji, pozitivan efekt zabilježen je u produktivnosti, s povećanjem od $25 \%$, što posljedično može dovesti do povećanja isporuke mljekarama za oko $17 \%$. Preliminarni rezultati Polaznog scenarija pokazuju povoljnu situaciju za hrvatski mljekarski sektor do 2025. godine u skladu s prilikama na tržištu EU, s mogućnošću povećanja proizvodnje obzirom na sadašnju razinu cijena na tržištu EU i svjetskim tržištima, uzimajući u obzir ukidanje mliječnih kvota. Također, rezultati navode na zaključak, prema iskustvima drugih članica, da će iskorištenje sredstava I. i II. stupa ZPP-a (iskorištavanja mjera preko projekata) u smislu poboljšanja proizvodnje, strukture i učinkovitost igrati najvažniju ulogu.

Ključne riječi: mlijeko i mliječni proizvodi, Zajednička poljoprivredna politika, parcijalna ravnoteža, model, projekcija

\section{References}

1. Boulanger, P., Ferrari, E., Michalek, J., Vinyes, C. (2013): Analysis of the impact of Croatia's accession to the EU on the agri-food sectors. A focus on trade and agricultural policies. Available at: http://knjiznica.sabor.hr/pdf/E_ publikacije/Analysis_of_the_impact_of_Croatia's_accession.pdf (1.10.2014.)

2. Chantreuil, F., Donnellan, T., van Leeuwen, M., Salamon, P., Tabeau, A. Bartova, L. (2008): EU Dairy Quota Reform - AGMEMOD Scenario Analysis. Proceedings of $12^{\text {th }}$ Congress of the European Association of Agricultural Economists - EAAE 2008. Gent, Belgium.

3. Chantreuil, F., Hanrahan, K., Leeuwen van, M. (2012): The Future of EU Agricultural Markets by AGMEMOD. Eds. Springer, p.128. doi: 10.1007/978-94-007-2291-0

4. Croatian Bureau of Statistics (2014): Cow's milk and dairy products June 2014, First release Number 1.1.26/6, 12 August 2014, Available at: http://www.dzs. hr/Hrv_Eng/publication/2014/01-01-26_06_2014.htm (15.9.2014.)

5. Croatian Bureau of Statistics (2014): Annual purchase and sale of products of agriculture, forestry and fishing, 2013 February 2014, First release Number 1.1.3, 24 February 2014, Available at: http://www.dzs.hr/ default_e.htm (12.1.2015.) 
6. DairyCO Market Information (2014): EU dairy product production. United Kingdom. Available at: http:// www.dairyco.org.uk/resources-library/market-information/dairy-market-update/\#.VGSw9DSG8Vw (10.11.2014.)

7. Eurostat (2013): Economic accounts for agriculture values at current prices. European Commission. Available at: http://appsso.eurostat.ec.europa.eu/nui/submitViewTableAction.do (12.11.2014.)

8. Eurostat (2014): Fat contents and protein contents (cow's milk) - annual data. European Commission. Available at: http://epp.eurostat.ec.europa.eu/portal/page/portal/ statistics/search_database. (15.10.2014.)

9. Eurostat (2014): Milk and milk products. Milk collection (all milks) and dairy products obtained - annual data. European Commission. Available at: http://epp.eurostat. ec.europa.eu/portal/page/portal/statistics/search_database. (15.10.2014.)

10. Franić, R., Marinović, M., Zrakić, M. (2011): Utjecaj državnih potpora na vrijednost i samodostatnost poljoprivredne proizvodnje u Hrvatskoj, Agronomski glasnik 73 (4-5), 227-244.

11. Grbić, V., Milanović, M., Đorović, M. (2010): Ekonomska analiza sistema kvota za mleko u agrarnoj politici Evropske unije, Ekonomika poljoprivrede 57 (4), 515-528.

12. Jurišić, Ž. (2013): Hrvatska poljoprivreda u Zajedničkoj poljoprivrednoj politici Europske unije: sadašnjost i sutrašnjica. Radovi Zavoda za znanstveni rad HAZU Križevci 1, 213-227.

13. Kotevska A., Dimitrievski D., Erjavec E. (2013): Macedonian livestock, dairy and grain sectors and the EU accession impact, Agric. econ. - Czech 59 (3), 125-133.
14. Market information system (MIS/Tisup) (2014): Prices: Raw milk and milk products. Available at: http://www. tisup.mps.hr/ (16.10.2014.)

15. Mljekarski list (2013): Republika Hrvatska u Europskoj uniji, Mljekarski list 7, 3-8.

16. Muminović, S., Pavlović, V. (2012): Profitability of dairy industry in Slovenia, Croatia and Serbia, Mljekarstvo 62 (2), 96-110.

17. Prišenk, J., Turk, J., Rozman, Č., Borec, A. Zrakić, M., Pažek, K. (2014): Advantages of combining linear programming and weighted goal programming for agriculture application, Operational Research 14 (2), 253-260. doi: 10.1007/s12351-014-0159-4

18. Salputra, G., Chantreuil, F., Hanrahan, K., Donnellan, T., Leeuwen van, M., Erjavec, E. (2011): Policy harmonized approach for the EU agricultural sector modelling, Agricultural and Food Science 20, 119-130. doi: 10.2137/145960611797215655

19. Šakić Bobić, B. (2013): Izgledi europskog mljekarstva u skoroj budućnosti, Mljekarski list 11, 12-15.

20. Šakić Bobić, B., Grgić, Z., Njavro, M. (2009): Djelovanje politike EU-a na mljekarstvo, Mljekarstvo 59 (2), 125132.

21. Zrakić, M., Grgić, I., Nedanov, A. (2014): Primjena metode modeliranja u sektorskoj analizi, Zbornik radova 49. hrvatskog \& 9. međunarodnog simpozija agronoma u Dubrovniku/Marić, Sonja; Lončarić, Zdenko (ur.) Osijek: Poljoprivredni fakultet Sveučilišta Josipa Jurja Strossmayera u Osijeku, 191-196. 